\title{
Pelatihan dan Pendampingan Pembuatan Gula Semut di Desa Patoman, Kecamatan Blimbingsari, Kabupaten Banyuwangi
}

\author{
I Wayan Pardi ${ }^{1}$, I Kadek Yudiana ${ }^{2}$, Miskawi ${ }^{3}$ \\ Program Studi Pendidikan Sejarah, Universitas 17 Agustus 1945 Banyuwangi \\ E-mail: iwayanpardi65.gmail.com ${ }^{1}$, yudihell@yahoo.co.id ${ }^{2}$, \\ miskawihistory@yahoo.co.id ${ }^{3}$
}

\begin{abstract}
ABSTRAK
Tujuan pengabdian ini adalah untuk melatih masyarakat dalam memproduksi dan melakukan pengemasan gula semut berbahan nira kelapa. Lokasi pengabdian berada di Dusun Patoman Tengah, Desa Patoman, Kecamatan Blimbingsari, Kabupaten Banyuwangi. Sementara itu, mitra yang dijadikan objek pengabdian adalah kelompok masyarakat tidak produktif dalam meproduksi gula merah dan masyarakat yang dulu pernah memproduksi gula merah cetak akan tetapi sekarang sudah berhenti karena berbagai macam masalah. Metode yang digunakan dalam pelatihan ini adalah dengan mendatangkan tenaga ahli dari Desperindag Banyuwangi yang menguasai bidang pembuatan gula semut. Proses produksi gula semut di Desa Patoman dimulai dari penyaringan nira kelapa menggunakan kain penyaring untuk membuang kotoran-kotoran, nira kelapa yang sudah bersih selanjutnya dimasukkan ke dalam wajan dan kemudian dimasak dengan kompor. Setelah nira kepala menjadi kental dilanjutkan dengan solidifikasi (pemadatan). Nira kelapa yang sudah padat terus diaduk hingga menjadi kristal (pengkristalan). Setelah berbentuk kristal dilakukan pula penghalusan dengan menggunakan ulekan berbahan kayu. Setelah itu dilakukan penyaringan dengan menggunakan ayakan yang sudah disiapkan. Gula semut selanjutnya dikeringkan dibawah sinar matahari selama 3-4 jam. Terakhir dilakukan pengemasan gula semut dengan menggunakan plastik dan botol plastik.
\end{abstract}

Kata Kunci: Gula Semut, Pelatihan, Pengemasan, Produksi

\begin{abstract}
The purpose of this service is to train the community in producing and packaging sugar ants made from coconut sap. The service location is in Patoman Tengah Hamlet, Patoman Village, Blimbingsari District, Banyuwangi Regency. Meanwhile, the partners that were made the object of service were unproductive groups of people in producing brown sugar and people who had previously produced printed red sugar but had now stopped because of various kinds of problems. The method used in this training is to bring in experts from the Desperindag Banyuwangi who master the field of making ant sugar. The sugar production process of ants in Patoman Village starts from filtering coconut sap using a filter cloth to remove impurities, the clean coconut juice is then put into a pan and then cooked with a stove. After the head juice becomes thick, it is continued by solidification (compaction). Solid coconut sap continues to stir until it becomes a crystal (crystallization). After the crystal is formed, refinement is also carried out by using wood made of pressure. After that filtering is done using a sieve that has been prepared. The ant sugar is then dried under the sun for 3-4 hours. Finally, the packaging of ant sugar is done using plastic and plastic bottles.
\end{abstract}

Keywords: Ant Sugar, Packaging, Production, Training. 
I Wayan Pardi', I Kadek Yudiana ${ }^{2}$, Miskawi ${ }^{3}$ /Aksiologiya: Jurnal Pengabdian Kepada Masyarakat. Vol.3, No.1, Februari 2019 Hal 84 - 93

\section{PENDAHULUAN}

Desa Patoman adalah salah satu desa yang terletak di Kecamatan Blimbingsari, Kabupaten Banyuwangi, Provinsi Jawa Timur. Desa Patoman merupakan desa yang terletak di dataran rendah yang luas wilayahnya mencapai 334.8 Ha. Luas wilayah Desa Patoman tersebut digunakan untuk persawahan sebayak 30,7 Ha atau $9,17 \%$, digunakan untuk perkebunan rakyat seluas $257.0 \mathrm{Ha}$ atau $76,76 \%$, digunakan untuk tambak seluas $10.0 \mathrm{Ha}$ atau 2,99\% dan yang digunakan untuk pemukiman mencapai $16.3 \mathrm{Ha}$ atau 4,87\%, sedangkan sisanya yang mencapai $20,8 \mathrm{Ha}$ atau $6,21 \%$ merupakan fasiltas umum seperti jalan, kuburan, lapangan, tempat ibadah, sekolah, sungai, dan prasarana lainnya (Monografi Desa Patoman Tahun 2017).

Peruntukan lahan perkebunan rakyat mencapai 257,0 hektar atau $76,76 \%$ dari total luas Desa Patoman yang mencapai 334,8 hektar sebagian besar dimanfaatkan untuk budidaya pohon kelapa. Kelapa adalah jenis tanaman serba guna karena hampir semua bagian tanaman ini bermanfaat bagi kehidupan manusia (Mahmud dan Yulius Ferry, 2005: 56). Dari pohon kelapa dapat diperoleh bahan makanan, minuman, bahan industri, bahan bangunan, dan alat-alat rumah tangga serta dapat dibuat kerajinan yang memiliki nilai jual. Buah kelapa dapat dimanfaatkan dengan cara diolah menjadi kopra, minyak kelapa, parutan kelapa kering, serat sabut kelapa, arang tempurung, nira dan gula kelapa, serta nata de coco. Sebagian besar masyarakat Desa Patoman memanfaatkan kelapa untuk dijadikan produk gula cetak/gula jawa.

Gula kelapa atau gula merah adalah gula yang terbuat dari bahan baku utama nira kelapa yang memiliki ciri khusus baik rasa, aroma dan bentuknya, yang sangat berbeda dengan gula putih yang terbuat dari bahan tebu (Heri dan Lukman, 2007: 74). Nira merupakan cairan bening yang terdapat dalam tandan bunga kelapa yang belum terbuka dan didapatkan dengan cara menyayat bagian tandan bunga kelapa sehingga dari luka tersebut keluar cairan bening yang memiliki rasa manis.

Menurut Endrasari dan Dian Maharso Yuwono (2012: 460) nira atau legen dalam bahasa Jawa yang artinya "legi/manis" adalah hasil sekresi dari tumbuhan dari keluarga Palmae, seperti kelapa, lontar, aren, kurma, sawit, sagu, siwalan dan lain sebagainya. Gula kelapa merupakan produk yang baik dikonsumsi untuk menjaga kesehatan bagi manusia karena memiliki keunggulan. Hal ini disebabkan karena kandungan akan sukrosa yang terdapat dalam gula pasir lebih tinggi jika dibandingkan dengan kandungan sukrosa pada gula kelapa sehingga baik dikonsumsi untuk penderita diabetes (Watemin, dkk., 2017: 15). Apalagi, kondisi masyarakat saat ini mulai menyadari akan pentingnya pola hidup yang sehat yang ditandai dengan mengkonsumsi produk-produk yang alami membuka peluang untuk pengembangan produk gula merah. 
Memproduksi gula merah sebenarnya sangat berpotensi untuk meningkatkan pendapatan masyarakat Desa Patoman, akan tetapi hal tersebut belum sepenuhnya dilakukan karena adanya berbagai masalah baik dalam pengadaan bahan baku, proses produksi, pengemasan, pemasaran, harga bahkan persaingan bisnis. Permasalahan utama yang ditemukan pada produsen gula merah adalah kurangnya kreatifitas masyarakat dalam menghasilkan produk gula kelapa yang lebih bervariasi. Produsen gula merah hanya mengolah gula merah menjadi bentuk tempurung kelapa/mangkok bundar atau berbentuk lingkaran bola. Padahal gula kelapa sebenarnya dapat diolah menjadi berbagai macam bentuk dan ukuran, salah satunya dibentuk menjadi gula semut atau gula bentuk serbuk. Apalagi gula semut dapat dijual dengan harga lebih tinggi dibandingkan dengan harga gula merah batok. Di Banyuwangi harga gula semut perkilogramnya bisa mencapai harga $\mathrm{Rp}$ 40.000-Rp 50.000. Sedangkan, harga gula merah cetak di Desa Patoman hanya hanya berkisar antara Rp 9.000-Rp 11.000 perkilo.

Selain itu, dalam pengadaan bahan baku pembuatan gula merah juga terdapat masalah adanya pembagian yang kurang kurang wajar antara penderes (orang yang bertugas memanen nira kelapa) dengan pemiliki pohon kelapa. Di Desa Patoman sistem pembagian nira kelapa antara penderes dengan pemilik pohon kelapa adalah sistem bagi hasil 3 banding 1 . Dengan perbandingan 3 kali produksi nira kelapa akan dimiliki oleh penderes, sedangkan 1 kali produksi dimiliki pemilik pohon kelapa. Hal ini tentu saja sangat merugikan pemilik pohon kelapa karena dalam 4 kali produksi nira kelapa, pemilik hanya mendapatkan 1 bagian. Oleh sebab itu tidaklah mengherankan apabila banyak pemilik pohon kelapa memutuskan untuk tidak lagi memproduksi nira kelapa.

Pada aspek produksi, permasalahan yang dihadapi produsen gula kelapa adalah alat-alat yang digunakan untuk memproduksi gula merah masih sangat konvensional atau tradisional. Bahan utama untuk pembuatan gula merah ini ialah air nira dari pohon kelapa. Setelah bahan yang diperlukan sudah dipersiapkan kemudian air nira dimasak sampai matang hingga berubah warna kecoklatan dan kemudian dicetak menggunakan batok kelapa. Dilihat dari segi waktu dan sumber daya manusianya proses produksi secara manual kurang efektif dan efisien.

Gula kelapa sebenarnya merupakan komoditas yang memiliki prospek yang bagus, karena permintaan yang tinggi dari dalam maupun luar negeri (Endrasari dan Dian Maharso Yuwono, 2012: 465). Prospek yang cukup cerah dari gula kelapa belum diikuti dengan cerahnya kehidupan produsen gula kelapa. Harga gula yang murah dan ditunjang posisi tawar produsen yang lemah, teknologi pengolahan masih sederhana sehingga produk yang dihasilkan kurang menarik, belum intensifnya pembinaan dari instansi/ lembaga terkait serta kurangnya 
sentuhan ilmu pengetahuan dan teknologi produsen gula merupakan beberapa penyebab tidak optimalnya pendapatan produsen gula kelapa. Maka, tidak mengherankan kalau ada pepatah yang mengatakan "nasib pengolah gula tidak semanis gula yang dihasilkan".

Berdasarkan analisis situasi di atas, dirasa sangat perlu untuk mengembangkan produk gula merah menjadi produk yang bernilai jual tinggi dan relevan dengan kebutuhan pasar di era modern. Oleh karena itu, untuk menyikapi tantangan yang dihadapi pengusaha gula kelapa di Desa Patoman maka pengabdian dengan judul "Pelatihan dan Pendampingan Pembuatan Gula Semut Di Desa Patoman, Kecamatan Blimbingsari, Kabupaten Banyuwangi" menjadi penting untuk dilakukan.

\section{METODE PELAKSANAAN}

Lokasi pengabdian pada masyarakat dengan judul "Pelatihan dan Pendampingan Pembuatan Gula Semut Di Desa Patoman, Kecamatan Blimbingsari, Kabupaten Banyuwangi" dilaksanakan di Dusun Patoman Tengah, Desa Patoman, Kecamatan Blimbingsari, Kabupaten Banyuwangi. Sementara itu, mitra yang dijadikan objek pengabdian adalah kelompok masyarakat tidak produktif dalam meproduksi gula merah dan masyarakat yang dulu pernah memproduksi gula merah cetak akan tetapi sekarang sudah berhenti karena berbagai macam masalah.

Adapun pertimbangan dalam pemilihan mitra ini karena mitra lebih terbuka untuk mendapatkan transfer pengetahuan dan pelatihan dari pihak luar, sedangkan kelompok-kelompok yang sudah produktif dalam memproduksi gula merah cenderung tertutup dan antipasti terhadap adanya pelatihan-pelatihan yang hendak dilaksanakan oleh pihak luar. Alasan lainnya dalam pemilihan kelompok masyarakat tidak produktif dalam meproduksi gula merah adalah adanya kecenderungan dari mitra (terutama ibu-ibu) yang sebagai besar waktunya hanya dilakukan untuk menjahit janur dan ngerumpi, sehingga kebutuhan dapur keluarga hanya mengandalkan penghasilan suami.

Metode yang digunakan dalam pelatihan ini adalah dengan mendatangkan tenaga ahli dari Disperindag Banyuwangi yang menguasai bidang pembuatan gula semut. Adapun metode pengolahan nira kelapa hingga menjadi gula semut adalah sebagai berikut.

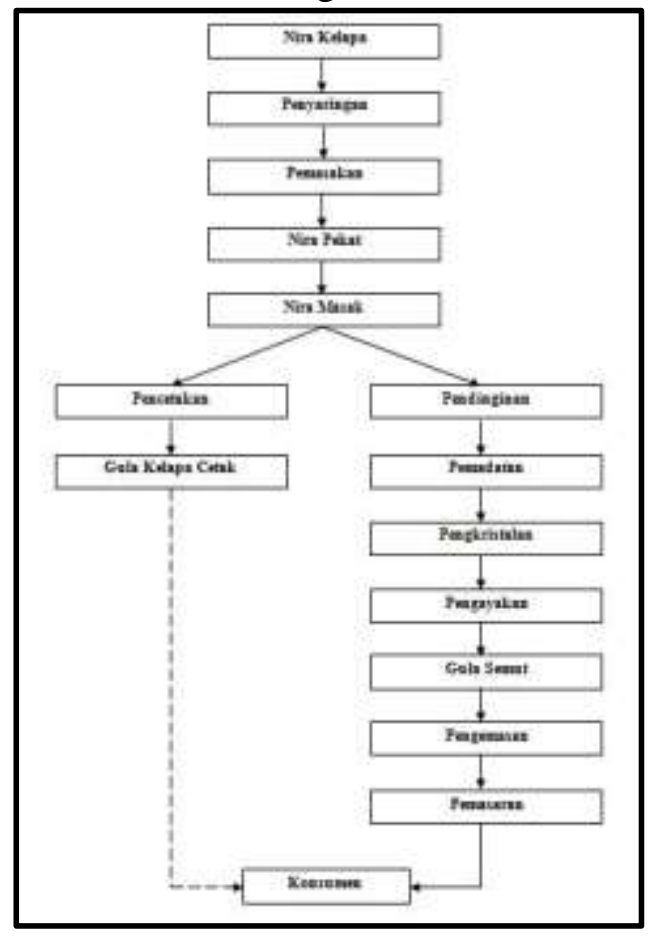

Gambar 1: Alur Produksi Gula Semut 
HASIL DAN PEMBAHASAN

Sosialisasi Keunggulan Gula Semut Dan Peluang Pasarnya

Sebelum kegiatan pelatihan pembuatan gula semut berbahan nira kelapa dilaksanakan, perwakilan dari Disperindag Banyuwangi, yaitu One Pranata menyampaikan materi mengenai keunggulan gula semut jika dibandingkan dengan gula cetak (bentuk gula tradisional/ konvensional). Kegiatan ini bertujuan untuk memotivasi perserta untuk mengembangkan industri pengolahan gula semut, sehingga masyarakat tidak hanya terpaku pada pengolahan gula cetak. Narasumber memberikan contoh gula semut berbahan aren yang telah diproduksi oleh masyarakat di Desa Pakistaji dan telah sukses di pasaran.

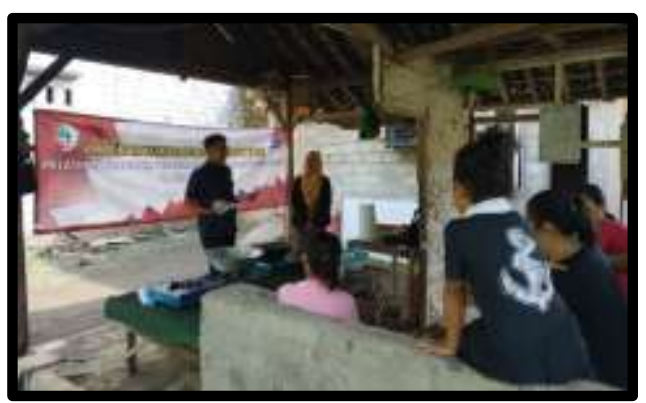

Gambar 2: Penyampaian Keunggulan Gula Semut

Sumber: Dokumentasi Pribadi

Kemudian, secara singkat narasumber juga menyampaikan bahwa gula semut atau gula bubuk atau gula kristal berbahan nira kelapa atau nira aren memiliki keunggulan jika dibandingkan dengan gula cetak/bentuk gula tradisional, yaitu gula semut mampu bertahan dalam jangka waktu yang cukup lama (satu sampai dua tahun) tanpa mengalami perubahan warna dan rasa jika dibungkus dengan pembungkus kedap udara. Jika ditinjau dari aspek ekonomi, gula semut juga memiliki harga jual yang cukup tingggi, untuk $1 \mathrm{~kg}$ gula semut harganya mencapai Rp. 40.000-Rp. 50.000 di petani, bandingkan dengan harga gula cetak yang hanya Rp. 9.000-Rp. 11.000 untuk $1 \mathrm{~kg}$. Narasumber juga menyampaikan bahwa di Banyuwangi kebutuhan konsumsi gula semut maupun untuk dikirim ke luar kota mencapai 1 ton perbulan, namun untuk sekarang baru bisa dipenuhi beberapa kilo saja, sehingga peluang pengembangan gula semut memiliki prospek pasar yang sangat bagus. Terkhir Narasumber menekankan bahwa jika masyarakat di Desa Patoman kedepannya akan mengembangkan gula semut maka Disperindag Banyuwangi akan siap memberikan pendampingan secara berkelanjutan, membantu persyaratan administrasi produk sehingga layak konsumsi, dan dalam pemasarannya.

\section{Proses Pembuatan Gula Semut Di Desa Patoman}

\section{Persiapan Bahan Baku dan Alat-Alat}

Proses pembuatan gula semut berbahan nira kelapa dapat dilakukan dengan dua cara, yaitu pertama dibuat dari air nira kelapa hasil sadapan yang selanjutnya diolah menjadi gula semut dan kedua gula semut yang dibuat dari gula cetak yang sudah jadi (reprosesing). Pada proses produksi gula semut dengan menggunakan nira kelapa yang harus diperhatikan 
adalah kualitas nira (jangan sampai nira menjadi asam). Jika nira yang telah menjadi asam diolah menjadi gula semut, maka tidak menghasilkan gula yang mengkristal. Sementara itu, alat-alat yang digunakan dalam pelatihan pengolahan air nira kelapa hingga menjadi gula semut adalah wajan, kompor, sendok kayu, saringan, ayakan baskom, dan loyang. Pada pembuatan gula semut juga tidak ada tambahan bahan lain yang digunakan, hanya air nira kelapa.

\section{Pengolahan Bahan Baku}

Berikut ini adalah mekanisme pengolahan nira kelapa hingga menjadi gula semut, yaitu:

a. Air nira disaring dengan menggunakan kain penyaring untuk membuang kotorankotoran, seperti daun kering, rating, lebah, semut dan serangga lainnya, sehingga tidak ada kotoran yang terdapat di dalam nira kelapa.
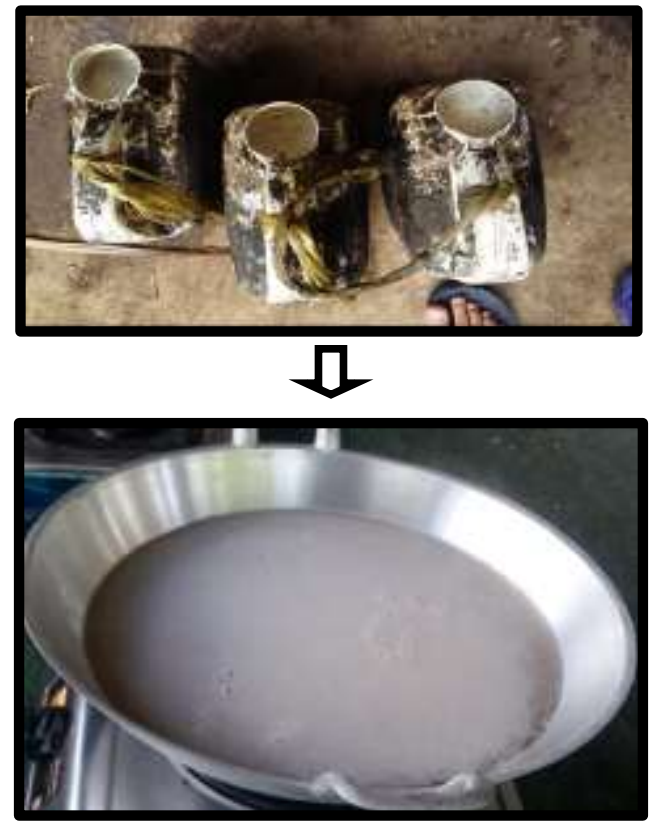

Gambar 3: Nira kelapa setelah disaring Sumber: Dokumentasi Pribadi Tim PKM b. Nira hasil saringan secepatnya dimasukkan ke dalam wajan dan kemudian dimasak dengan kompor sampai suhu $110-120^{\circ} \mathrm{C}$. Pengolahan air nila nira hasil saringan dilakukan secepatnya agar air nira tidak menjadi masam. Pada saat pemasakan kotoran-kotoran halus akan terapung di permukaan bersama-sama busa nira. Kotoran tersebut, lalu dibuang dengan menggunakan sendok. Pada pemanasan ini pula, akan timbul busa nira yang meluap-luap berwarna kuning hingga cokelat.

c. Langkah selanjutnya adalah mengaduk air nira yang sudah panas agar busa nira tidak meluap dari wajan. Air nira yang semula berwarna putih kekuningan, lambat laun akan jadi tua, dan pada ssaat buih-buih nira turun berarti nira sudah mulai pekat. Pada saat ini harus dihindari terjadinya pemasakan nira yang melewati titik end point, yakni berkisar $110^{\circ} \mathrm{C}$. End point merupakan suhu akhir pemasakan, dimana nira sudah mulai kental dan meletup letup. Penentuan end point diketahui secara visual, yaitu nira yang dipanaskan akan menggumpal (memadat dan mengeras) dan tidak bercampur dengan air jika dituang ke dalam air dingin.

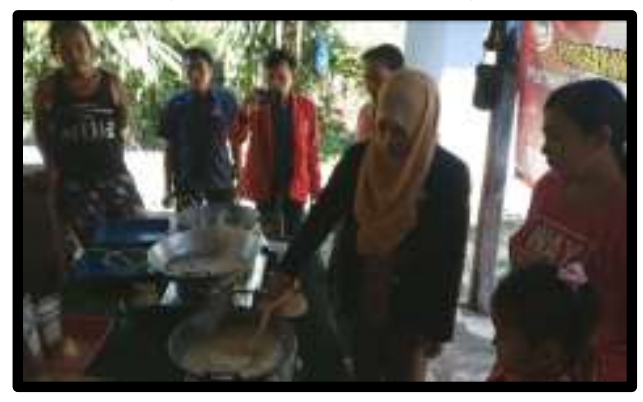

Gambar 4: Pengadukan Air Nira Kelapa 
d. Setelah diperoleh nira kental dilanjutkan dengan solidifikasi (pemadatan) Proses solidifikasi dilakukan dengan cara pendinginan, yakni nira yang telah masak didinginkan dalam wajan sambil diaduk secara perlahan-lahan, lama pendinginan 10-15 menit.

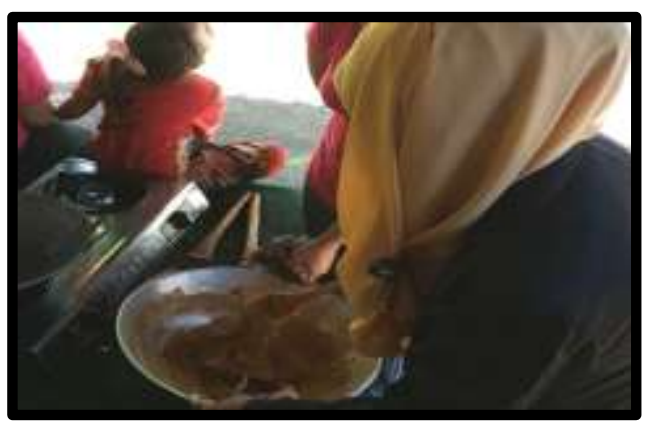

Gambar 5: Solidifikasi (Pemadatan)

e. Selanjutnya, proses kristalisasi (pengkristalan) dilakukan dengan cara pengadukan menggunakan sendok kayu. Pengadukan dilakukan secara perlahan-lahan, dimulai dari bagian pinggir ke bagian tengah wajan. Bila mulai terbentuk butiran-butiran, pengadukan dipercepat dengan menggunakan pengaduk kayu. Setelah berbentuk kristal dilakukan pula penghalusan dengan menggunakan ulekan.

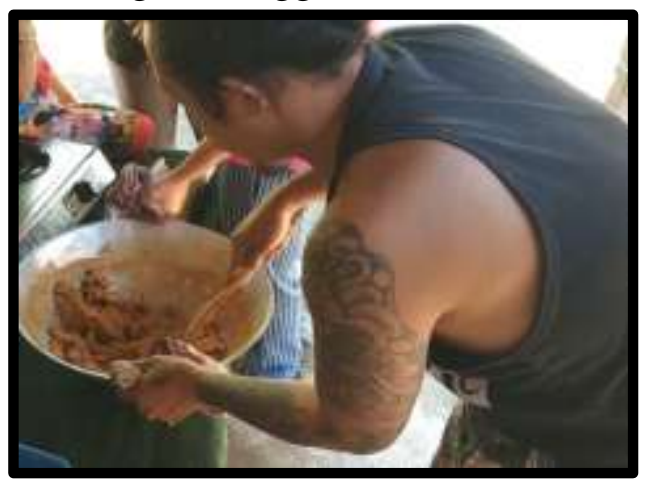

Gambar 6: Proses Kristalisasi (Pengkristalan) f. Setelah gula kelapa berbentuk kristal, langkah selanjutnya adalah dilakukan penyaringan dengan menggunakan ayakan yang sudah disiapkan. Tujuannya adalah untuk agar butiran-butiran gula semut memiliki komposisi ukuran yang tidak terlalu besar. Gula semut yang ukurannya terlalu besar atau masih menggumpal akan dihaluskan dengan menggunakan ulekan kayu agar menjadi halus dan kemudian diayak kembali.

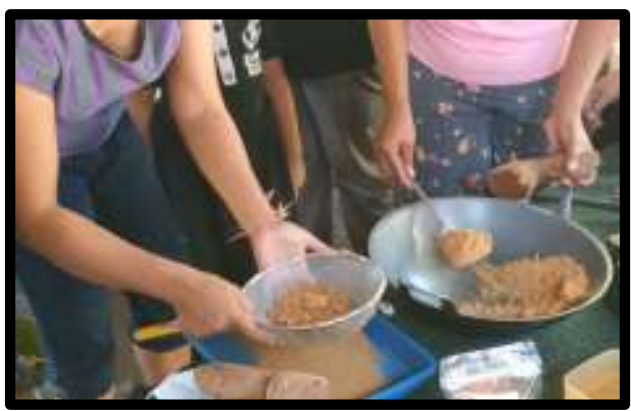

Gambar 7: Proses Pengayakan

g. Gula semut yang telah diproduksi selanjutnya dikeringkan. Pengeringan gula semut dapat dilakukan dengan dua cara, yaitu 1) pengeringan dengan sinar matahari selama 3-4 jam, dan 2) pengeringan dengan oven dengan suhu pengeringan $45^{\circ} \mathrm{C}-50^{\circ} \mathrm{C}$ selama 1,5-2,0 jam. Metode pengeringan yang digunakan pada gula semut pada pelatihan ini adalah pengeringan dengan sinar matahari selama 3-4 jam. Setelah gula semut benar-benar kering barulah pengemasan dapat dilakukan. 


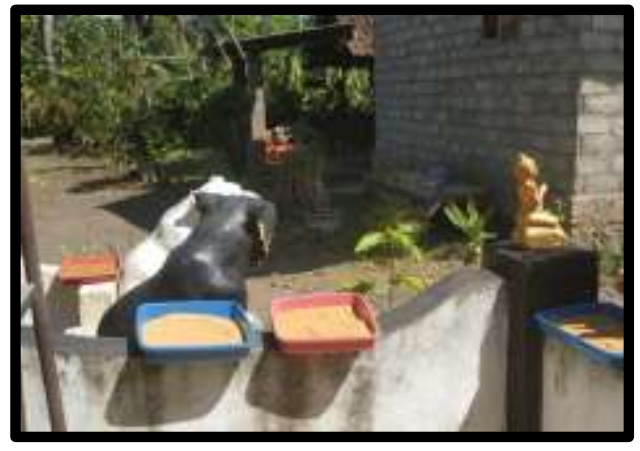

Gambar 8: Pengeringan Gula Semut

h. Setelah diperoleh serbuk gula semut yang telah diproduksi, selanjutnya dilakukan pengemasan gula semut. Gula semut kering dikemas dengan ukuran berat bervariasi, yaitu 100 gr, 250 gr, 500 gr dan 1000 gr (1 $\mathrm{kg})$. Pengemasan yang digunakan adalah dengan menggunakan plastik dan botol plastik yang tahan panas dan kedap air serta tidak mudah rusak. Adapun alatalat yang dibutuhkan dalam pengemasan gula semut adalah plastik dan botol berukuran 100 gr, 250 gr, 500 gr dan 1000 gr (1 $\mathrm{kg}$ ), timbangan, sendok makan, dan loyang plastik.

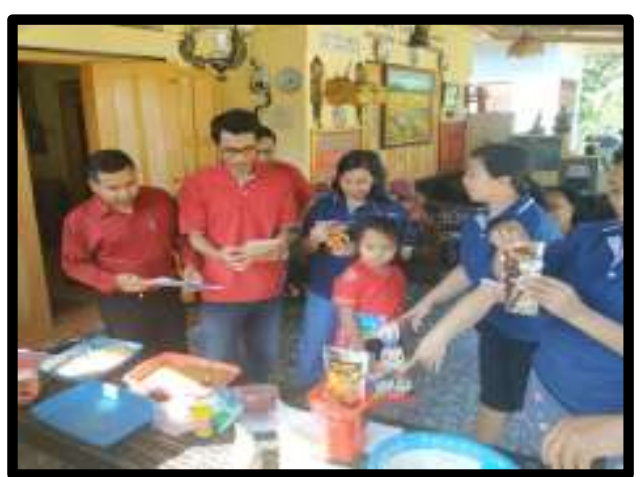

Gambar 9: Pengemasan Produk

\section{Produk Gula Semut Yang Dihasilkan}

Gula semut yang sudah diproduksi tidak serta merta langsung dipasarkan, akan tetapi terdapat revisi/perbaikan pada stiker kemasan yang digunakan. Revisi dilakukan dengan tujuan untuk membuat kemasan yang lebih menarik di mata konsumen, serta penambahan informasi lainnya mengenai produk gula semut.

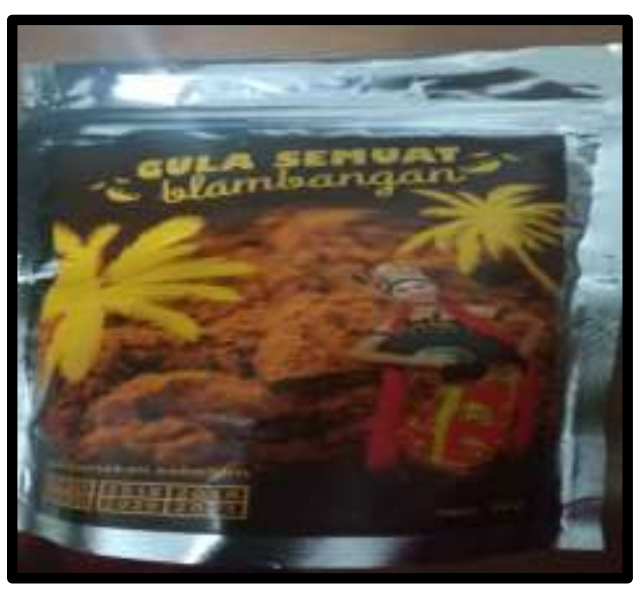

Gambar 10: Kemasan Produk Awal

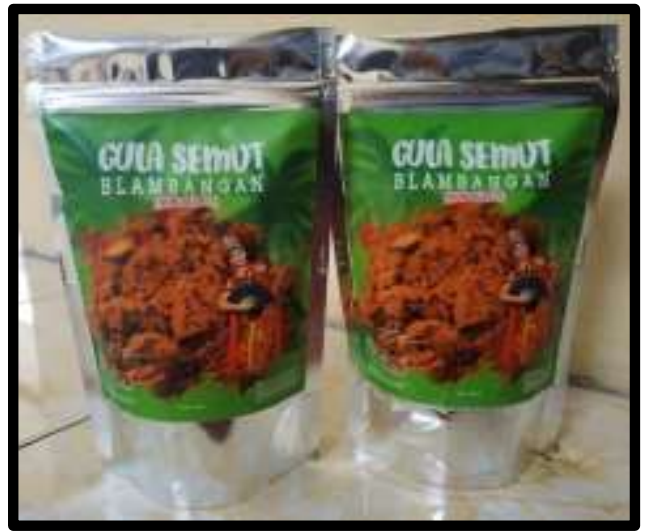

Gambar 11: Hasil Revisi Kemasan Produk Awal

Perbaikan yang dilakukan pada kemasan produk (stiker) gula semut adalah adanya pergantian bacgroud kemasan, yang semula berwarna coklat tua diganti menjadi warna hijau. Tujuannya agar kemasan gula semut dapat mewakili karakter gula semut yang bersifat natural/alami tanpa bahan pengawet. Kemudian juga dilakukan 
penambahan kata non-sulfit pada merk produk. Tujuannya agar konsumen mengetahui bahwa produk gula semut tersebut adalah gula semut yang dibuat tanpa menggunakan bahan pengawet, sehingga aman dikonsumsi oleh masyarakat. Selain itu juga terdapat tanbahan informasi lainnya terkait dengan produk gula semut, yaitu dapat dilihat pada gambar di bawah ini.

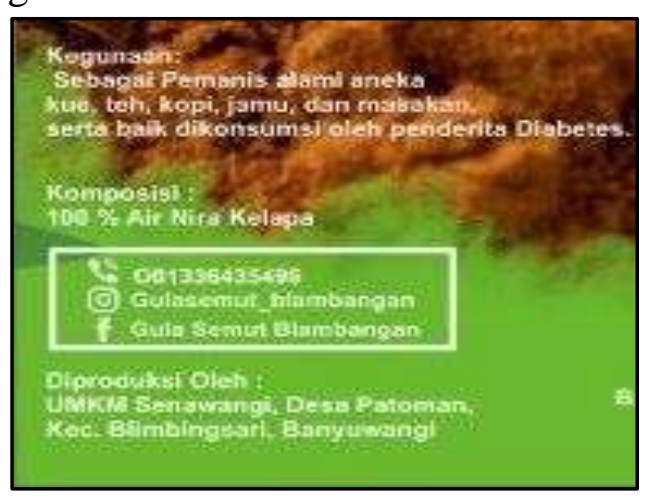

Gambar 12: Tambahan Informasi Pada Kemasan Produk

Pada gambar di atas terlihat bahwa pada kemasan ditambahkan informasi kegunaan gula semut, komposisi gula semut, alamat pemesanan gula semut mulai dari nomor handphone, alamat instagram, dan Facebook. Kemudian juga terdapat produsen gula yaitu, UMKM Senawangi, yang beralamat di Desa Patoman, Kecamatan Blimbingsari, Kabupaten Banyuwangi.

\section{SIMPULAN}

Kegiatan pelatihan dan pendampingan proses pembuatan gula semut di Desa Patoman diawali dengan penyiapan bahan baku utama pembuatan gula semut, yaitu nira kelapa. Sementara itu, alat-alat yang digunakan dalam pelatihan pengolahan air nira kelapa hingga menjadi gula semut adalah wajan, kompor, sendok kayu, saringan, ayakan baskom, dan loyang. Adapun proses produksinya dimulai dari penyaringan nira kelapa menggunakan kain penyaring untuk membuang kotoran-kotoran, kemudian nira hasil saringan secepatnya dimasukkan ke dalam wajan dan kemudian dimasak dengan kompor. Air nira yang semula berwarna putih kekuningan, lambat laun akan jadi tua, dan setelah diperoleh nira kental dilanjutkan dengan solidifikasi (pemadatan). Selanjutnya, nira yang sudah padat terus diaduk hingga menjadi kristal (pengkristalan). Setelah berbentuk kristal dilakukan pula penghalusan dengan menggunakan ulekan. Setelah itu dilakukan penyaringan dengan menggunakan ayakan yang sudah disiapkan. Gula semut selanjutnya dikeringkan dibawah sinar matahari selama 3-4 jam. Terakhir dilakukan pengemasan gula semut dengan menggunakan plastik dan botol plastik.

\section{DAFTAR PUSTAKA}

Endrasari, Retno dan Dian Maharso Yuwono.2012. Potensi Olahan Gula Kelapa Dalam Mendukung Pemanfaatan Pekarangan Di MKRPL Kabupaten Magelang. Prosiding Seminar Nasional Optimalisasi Pekarangan. Semarang 6 November 2012

Heri, M.K. dan Lukman, M. 2007. Pendampingan Penerapan Diversifikasi Produk Gula 
I Wayan Pardi', I Kadek Yudiana ${ }^{2}$, Miskawi ${ }^{3}$ /Aksiologiya: Jurnal Pengabdian Kepada Masyarakat. Vol.3, No.1, Februari 2019 Hal 84 - 93

Kelapa/Merah Kemasan Kecil.

Jurnal DEDIKASI Volume 4.

Halaman 73-81

Mahmud, Zainal dan Yulius Ferry.

2005. Prospek Pengolahan Hasil

Samping Buah Kelapa. Jurnal

Perspektif Volume 4 Nomor 2.

Halaman 55-63

Monografi Desa Patoman Tahun 2017

Watemin, dkk. 2017. Pelatihan Gmp

Dan Haccp Bagi Pengrajin Gula

Kelapa Kristal. Jurnal

Pengabdian Dan Pemberdayaan

Masyarakat (JPPM) Volume 1

Nomor 1. Halaman 14-19 